\title{
Calcaneal Pitch and Lateral Talocalcaneal Angle among Nigerians
}

\author{
Inclinación Calcáneo y Ángulo Talocalcáneo Lateral en Nigerianos
}

\author{
Ahmadu Usman Dahiru*; Samuel Adeniyi Ojo**; Ahmed Umdagas Hamidu**** \& Barnabas Danborno*
}

DAHIRU, A. U.; OJO, S. A.; HAMIDU, A. U. \& DANBORNO, B. Calcaneal pitch and lateral talocalcaneal angle among Nigerians. Int. J. Morphol., 31(2):528-532, 2013.

SUMMARY: Various papers in the fields of Radiology, orthopaedics and radiographic anatomy have employed the use of angles measured on X-rays to make diagnoses, select treatment modalities in the management of foot disorders as well as predicting the outcome of interventions to these disorders. Calcaneal pitch (CP) and lateral talocalcaneal angle (L TCA) are angles that can be drawn on lateral standing radiographs of the foot and are used widely in the diagnosis, prognosis and choice of treatment modalities for various disorders of the foot. Data on these important radiological tools are lacking in Nigeria. Hence, the study is an attempt to bridge this gap. Using a hinge goniometer, the angles were measured from normal lateral standing radiographs of the foot. Mean $\mathrm{CP}$ was found to be $15.08 \pm 2.87(n=63)$ and the mean L TCA was found to be $38.85^{\circ} \pm 8.20^{\circ}(n=130)$. Differences in the means of the angles seen between the sexes were not statistically significant $(\mathrm{CP}, \mathrm{p}=0.70$; L TCA, $\mathrm{p}=0.60)$. No such significant difference was also observed in mean of the angles with respect to the sides of the body $(\mathrm{CP}, \mathrm{p}=0.58$; L TCA, $\mathrm{p}=0.13)$ or between ethnic groups $(\mathrm{CP}, \mathrm{p}=0.30 ; \mathrm{L} \mathrm{TCA}, \mathrm{p}=0.40)$.

KEY WORDS: Calcaneal pitch; Lateral talocalcaneal angle; Nigerians.

\section{INTRODUCCIÓN}

Radiographs have been used as tools of diagnosis, prognosis and in selection and evaluation of treatment modalities of various types of deformities and fractures of the foot (Katz et al., 1997; Igbibi \& Mutesasira, 2003; Dooley et al., 2004; Dobbs et al., 2006; Westberry et al., 2007; Aminian \& Sangeorzan, 2008; Radler et al., 2010). Lateral talocalcaneal angle (L TCA) is an angle formed by a line along the long axis of the talus and another line along the long axis of the calcaneus on a standard weight bearing lateral radiograph of the foot. The angle is used widely in the diagnosis and choice of treatment modalities for club foot. It is also widely used in assessing hind foot valgus (Westberry et al.; Anad \& Sala, 2008), in assessment of treatment outcomes for planovalgus deformities (Knupp et al., 2009); assessment of treatment outcomes for sequelae of fractures of the calcaneus (Savva \& Saxby, 2007) and other forms of calcaneus deformity and club foot (Wisbrun, 1932; Aronson et al., 1983; Davids et al., 2007).

Calcaneal Pitch (calcaneal inclination angle) is an angle subtended by a line drawn along the lower border of the calcaneus and the plane of support of the foot in a standard weight bearing lateral radiograph of the foot (Gentili et $a l ., 1996)$. The average calcaneal pitch is $20.54^{\circ}$; a calcaneal pitch greater than $30^{\circ}$ is indicative of hind foot varus (Prichasuk \& Subhadrabandhu, 1994; Turner et al., 2005; Westberry et al.). It is lowered by such factors as excessive weight gain, aging and presence of a calcaneal spur. Its value is lower in females than in males. The angle is a measure of the alignment of hind foot and has widely been used by several researchers to make diagnosis (Schwend \& Drennan, 2003; Aminian \& Sangeorzan; Clare et al., 2005; Park et al., 2008; Knupp et al.; Mehrafshan et al., 2009).

The study was therefore aimed to determine the Normal Calcaneal pitch (CP) and Lateral Talocalcaneal angle (L TCA) of Nigerians; if there are differences in the observed means of the CP \& L TCA between the sexes, sides of the body and ethnic groups; the influence of age on the CP \& L TCA of Nigerians.

\footnotetext{
*Department of Human Anatomy, Ahmadu Bello University, Zaria, Nigeria.

**Department of Veterinary Anatomy, Ahmadu Bello University, Zaria, Nigeria.

***Department of Radiology, Ahmadu Bello University, Zaria, Nigeria.
} 


\section{MATERIAL AND METHOD}

This is a retrospective study done on standing lateral radiographs of the foot and ankle that were reported normal. The radiographs used in the study were those culled from X-ray libraries of Ahmadu Bello University Teaching Hospital (ABUTH), Zaria and National Orthopaedic Hospital (NOH) Dala, Kano. X-rays included in the study were those in which Demographic data of patients have been captured on the report or the X-ray film. The data of interest were age, sex, side of the body and ethnic group of Hausa, Igbo, Yoruba and Other Nigerian ethnic groups. X-rays with improper filling of $\mathrm{X}$-ray request form, previous or recent fracture of any bone of the foot, previous surgery of the foot or calcaneal fracture in the case of calcaneal pitch angle were excluded from the study. The points defining the angles on the X-rays were identified and marked with the X-ray pencil, a ruler was used in drawing straight lines that joined the points and the angles enclosed were then measured with a goniometer and recorded.

Statistical Analysis. Statistical analysis was done using Analyse-it for Microsoft Excel (version 2.22) software. All data were expressed as mean \pm standard deviation. Student $\mathrm{t}$-test was used in comparing means of the studied parameters between the sexes ant the sides of the body while analysis of variance (ANOVA) was used in determining the degree of the difference in the mean of the angles between the ethnic groups. Level of significance was put at $\mathrm{p} \leq 0.05$

\section{RESULTS}

The results of the study are as shown in Tables I and II. Table I shows the descriptive statistics of the calcaneal pitch angle and the lateral talocalcaneal angle of the whole sample and the description of the angles based on sex side of the body and ethnicity. The mean $\mathrm{CP}$ was found to be $15.08^{\circ} \pm 2.87^{\circ}$ while the mean L TCA was found to be $38.85^{\circ} \pm 8.20^{\circ}$. No statistically significant difference was observed in the mean of the angles between the sides of the body sexes or the ethnic groups studied. Table II shows the influence of age on these angles based of the aforementioned variables. Increasing age has a significantly decreasing effect on calcaneal pitch in many of the variables considered but lateral talocalcaneal angle was not significantly affected by age.

Table I. Descriptive Statistics of lateral talocalcaneal angle and calcaneal pitch.

\begin{tabular}{|c|c|c|c|c|c|c|c|}
\hline Parameter & \multicolumn{2}{|c|}{ Variable } & $\mathbf{n}$ & Mean \pm SD & Minimum & Maximum & $\mathbf{p}$ \\
\hline \multirow{8}{*}{$\mathrm{L} \mathrm{TCA}^{\circ}$} & \multicolumn{2}{|c|}{ Whole Sample } & 130 & $38.85 \pm 8.20$ & 18 & 56 & \multirow{3}{*}{0.13} \\
\hline & \multirow{2}{*}{ Side } & R & 56 & $41.09 \pm 6.76$ & 25 & 56 & \\
\hline & & $\mathrm{L}$ & 73 & $37.25 \pm 8.93$ & 15 & 53 & \\
\hline & \multirow{2}{*}{ Sex } & M & 96 & $39.07 \pm 8.57$ & 18 & 56 & \multirow{2}{*}{0.6} \\
\hline & & $\mathrm{F}$ & 34 & $38.21 \pm 7.14$ & 24 & 52 & \\
\hline & \multirow{3}{*}{ Tribe } & Hausa & 99 & $38.09 \pm 8.37$ & 17 & 56 & \multirow{4}{*}{0.40} \\
\hline & & Igbo & 13 & $41.65 \pm 7.46$ & 28.5 & 53 & \\
\hline & & Yoruba & 4 & $36.75 \pm 10.93$ & 22 & 48 & \\
\hline \multirow{10}{*}{$\mathrm{CP}^{\circ}$} & & Others & 14 & $40.71 \pm 8.60$ & 25 & 52 & \\
\hline & \multicolumn{2}{|c|}{ Whole Sample } & 63 & $15.08 \pm 2.87$ & 10 & 23 & \multirow{3}{*}{0.58} \\
\hline & \multirow{2}{*}{ Side } & $\mathrm{R}$ & 30 & $14.87 \pm 2.87$ & 10 & 21 & \\
\hline & & $\mathrm{L}$ & 36 & $15.53 \pm 3.87$ & 6 & 25 & \\
\hline & \multirow{2}{*}{ Sex } & M & 45 & $14.99 \pm 2.75$ & 10 & 23 & \multirow{2}{*}{0.7} \\
\hline & & F & 18 & $15.31 \pm 3.22$ & 12 & 22 & \\
\hline & \multirow{4}{*}{ Tribe } & Hausa & 51 & $15.42 \pm 2.94$ & 12 & 25 & \multirow{4}{*}{0.30} \\
\hline & & Igbo & 6 & $15.83 \pm 6.31$ & 6 & 24 & \\
\hline & & Yoruba & 3 & $11.00 \pm 1.73$ & 9 & 12 & \\
\hline & & Others & 6 & $12.75 \pm 1.84$ & 10 & 15 & \\
\hline
\end{tabular}


Table II. Predictive equation of lateral talocalcaneal angle and calcaneal pitch.

\begin{tabular}{|c|c|c|c|c|c|c|c|c|c|}
\hline Parameter & & Side & Predictive Equation & $\mathbf{n}$ & SEE & $\mathbf{r}$ & $\mathbf{r}^{2}$ & $\mathbf{t}$ & $\mathbf{p}$ \\
\hline \multirow{8}{*}{$\mathrm{L} \mathrm{TCA}^{\circ}$} & Wh & ample & $\mathrm{L}$ TCA $=40.02-0.039 \mathrm{Age}$ & 130 & 8.21 & 0.1 & 0.01 & 0.93 & 0.35 \\
\hline & \multirow{2}{*}{ Side } & $\mathrm{R}$ & $\mathrm{L} \mathrm{TCA}=42.64-0.09 \mathrm{Age}$ & 59 & 7.93 & 0.17 & 0.03 & 1.42 & 0.16 \\
\hline & & $\mathrm{L}$ & $\mathrm{L} \mathrm{TCA}=37.8+0.002 \mathrm{Age}$ & 71 & 8.35 & 0 & 0 & 0.03 & 0.98 \\
\hline & \multirow{2}{*}{ Sex } & M & $\mathrm{L} \mathrm{TCA}=41.19-0.069 \mathrm{Age}$ & 96 & 8.54 & 0.14 & 0.02 & 1.29 & 0.20 \\
\hline & & $\mathrm{F}$ & $\mathrm{L} \mathrm{TCA}=37.75+0.017$ Age & 34 & 7.24 & 0 & 0 & 0.25 & 0.80 \\
\hline & \multirow{3}{*}{ Tribe } & Hausa & $\mathrm{L}$ TCA $=39.16-0.03$ Age & 99 & 8.16 & 0 & 0 & 0.65 & 0.52 \\
\hline & & Igbo & $\mathrm{L} \mathrm{TCA}=41.81-0.005 \mathrm{Age}$ & 13 & 7.79 & 0 & 0 & 0.03 & 0.98 \\
\hline & & Yoruba & $\mathrm{L} \mathrm{TCA}=44.39-0.25 \mathrm{Age}$ & 4 & 12.42 & 0.37 & 0.14 & 0.57 & 0.63 \\
\hline \multirow{9}{*}{$\mathrm{CP}^{\circ}$} & & Others & $\mathrm{L} \mathrm{TCA}=45.98-0.16 \mathrm{Age}$ & 14 & 8.55 & 0.3 & 0.09 & 1.08 & 0.30 \\
\hline & \multicolumn{2}{|c|}{ Whole Sample } & $\mathrm{CP}=16.57-0.052 \mathrm{Age}$ & 63 & 2.77 & 0.28 & 0.08 & 2.34 & 0.02 \\
\hline & \multirow{2}{*}{ Side } & $\mathrm{R}$ & $\mathrm{CP}=17.41-0.01 \mathrm{Age}$ & 30 & 2.45 & 0.54 & 0.29 & 3.42 & 0.0019 \\
\hline & & $\mathrm{L}$ & $\mathrm{CP}=15.92-0.02 \mathrm{Age}$ & 33 & 2.93 & 0.1 & 0.01 & 0.62 & 0.54 \\
\hline & \multirow{2}{*}{ Sex } & M & $\mathrm{CP}=16.87-0.063 \mathrm{Age}$ & 45 & 2.63 & 0.33 & 0.11 & 2.29 & 0.03 \\
\hline & & $\mathrm{F}$ & $\mathrm{CP}=16.20-0.035 \mathrm{Age}$ & 18 & 3.25 & 0.2 & 0.04 & 0.84 & 0.41 \\
\hline & \multirow{3}{*}{ Tribe } & Hausa & $\mathrm{CP}=16.9-0.06 \mathrm{Age}$ & 50 & 2.48 & 0.36 & 0.13 & 2.66 & 0.01 \\
\hline & & Igbo & $\mathrm{CP}=19.17-0.17 \mathrm{Age}$ & 4 & 3.45 & 0.56 & 0.31 & 0.96 & 0.44 \\
\hline & & Others & $\mathrm{CP}=9.84+0.11 \mathrm{Age}$ & 7 & 4.2 & 0.41 & 0.17 & 1.03 & 0.35 \\
\hline
\end{tabular}

\section{DISCUSSION}

The stringent inclusion and exclusion criteria have limited the number of the X-rays available for this study to the extent that only 63 were suitable for studying calcaneal pitch and 130 for studying the lateral talocalcaneal angle. The data in the result of this study is comparable to those of Seyahi et al. (2010). In defining normal Böhler's angle these authors used 107 lateral radiographs.

The lateral talocalcaneal angle as observed from the present study is shown to range from $18^{\circ}$ to $56^{\circ}$. Beatson \& Pearson (1966) had reported that the normal range is $30-$ $50^{\circ}$ and this was later corroborated by Anand \& Sala. The upper and lower limits of the observed values from the study are slightly away from the normal; the lower value tends towards planus or valgus shape while the high value of the upper limit is tending towards a cavus or varus shape of the longitudinal arch (Westberry et al.; Anad \& Sala). However, this is not abnormal as Sangeorzan (2010) asserts that up to $24 \%$ of the population has cavus shape of the foot and that if anything affects that much population is, by definition, not abnormal. He further goes to mention that anything that common is likely to have variations in its anatomy. In all, the range can be said to be an addition to the varied levels of the normal for this angle. The calcaneal pitch angle as found in the study ranged from $10^{\circ}$ to $23^{\circ}$. This range is within normal limits when compared with the mean calcaneal pitch reported by Prichasuk \& Subhadrabandhu. These authors reported the mean calcaneal pitch to be $20.4^{\circ}$. The angle is a measure of the alignment of the hind foot with respect to the fore foot. The result is therefore indicative of normal curvature of the medial longitudinal arch of the foot. Turner et al. (2005), and Westberry et al., have reported that a calcaneal pitch angle greater than $30^{\circ}$ is indicative of pes cavus. Conversely, calcaneal pitch angle less than $10^{\circ}$ is indicative of pes planus (Park et al.; Mehrafshan et al.).

When the mean of the angles were compared based on sex and sides of the body, the differences in the means were not statistically significant. An attempt was also made to determine if there is a statistically significant difference in the mean of the parameters studied between the four ethnic groupings included in the study, but no such statistically significant differences were observed.

A predictive equation for the L TCA was calculated using a linear regression model and was found to be L TCA $=40.02-0.039$ Age. However, this was not found to be statistically significant at $p$ value of 0.35 . Results of the study showed a statistically significant negative linear relationship between age and calcaneal pitch with a slope of 0.052 and 
intercept of $16.57^{\circ}$ at $\mathrm{p}$ value of 0.02 . Thus calcaneal pitch at any given age is derived from the formula $\mathrm{CP}=16.57^{\circ}$ 0.052 Age. This observation is in agreement with the positions of Prichasuk \& Subhadrabandhu, Gentili et al. and Katz et al. These authors argued that as age increases, the calcaneal pitch tends to be lowered. When the calcaneal pitch was computed against age for the whole sample irrespective of the side of the body, from calcaneal pitch of $16.57^{\circ}$, this angle decreases by 0.052 factor of any given age. However, when the side of the body was taken in to consideration, it was found that the depreciation of the angle is only minimal; by a factor of 0.01 and 0.02 of the age for the right and left feet respectively, from their intercepts. As small as the change in value of the angle due to aging is, the change on the right was found to significant, statistically at $p$ value of 0.0019 . In males the calcaneal pitch drops by a factor of 0.063 of the age from an intercept of $16.87^{\circ}$. The decrease has been found to be statistically significant at $p$ value of 0.03 . This is not significantly so in the females. This also is in consonance with the report of Prichasuk \& Subhranbandhu who reported that the angle is lowered by increase in age. The authors further maintained that males have higher calcaneal pitch than females. They however did not put into consideration the combined effect of sex and age on this angle.

\section{CONCLUSION}

The mean calcaneal angle of Nigerians was found to be $15.08^{\circ}$ while the mean lateral talocalcaneal angle was $38.85^{\circ}$. No statistically significant difference was observed in the mean of the parameters between the sexes, sides of the body and ethnic groups. Lateral talocalcaneal angle is not affected by age but the calcaneal pitch shows a statistically significant decrease with increasing age.

It is recommended that this study should prospectively be replicated and that the influence of weight and other parameters of assessing nutrition on these angles be investigated.

\section{ACKNOWLEDGEMENTS}

The authors wish to acknowledge the assistance rendered by the staff members of Radiology Departments of Ahmadu Bello University Teaching Hospital, Zaria and National Orthopaedic Hospital, Dala Kano.

DAHIRU, A. U.; OJO, S. A.; HAMIDU, A. U. \& DANBORNO, B. Inclinación calcáneo y ángulo talocalcáneo lateral en Nigerianos. Int. J. Morphol., 31(2):528-532, 2013.

RESUMEN: Diversos trabajos en las áreas de la radiología, ortopedia y anatomía radiográfica han empleado los ángulos medidos en las radiografías para hacer diagnósticos, seleccionar las modalidades de tratamiento en el manejo de los trastornos del pie, así como para predecir el resultado de las intervenciones para estos trastornos. La inclinación calcánea (PC) y el ángulo talocalcáneo lateral (L TCA) son los ángulos que se pueden extraer desde las radiografías laterales de los pies y ser utilizados ampliamente en el diagnóstico, pronóstico y elección de modalidades de tratamiento para diversos trastornos del pie. Los datos sobre estos importantes instrumentos radiológicos no existen en Nigeria, y su estudio es un intento de obtener esta información. Usando un goniómetro bisagra, los ángulos se midieron a partir de radiografías normales permanentes lateral del pie. La media de CP se fue 15,08 $\pm 2,87$ ( $\mathrm{n}=63$ ) y la media de TCA L fue $38,85^{\circ} \pm 8,20^{\circ}(\mathrm{n}=130)$. Las diferencias en las medias de los ángulos observados entre los sexos no fueron estadísticamente significativas $(\mathrm{CP}, \mathrm{p}=0,70 ; \mathrm{L} \mathrm{TCA}, \mathrm{p}=0,60)$. No hubo diferencias significativas en la media de los ángulos con respecto al lado $(\mathrm{CP}, \mathrm{p}=0,58$; L TCA, $p=0,13)$ o entre grupos étnicos $(C P, p=0,30 ;$ L TCA, p =0,40).

PALABRAS CLAVE: Inclinación calcánea; Ángulo talocalcáneo lateral; Nigerianos.

\section{REFERENCES}

Aminian, A. \& Sangeorzan, B. J. The anatomy of cavus foot deformity. Foot Ankle Clin., 13(2):191-8, 2008.

Anand, A. \& Sala, D. A. Clubfoot: etiology and treatment. Indian J. Orthop., 42(1):22-8, 2008.

Aronson, J.; Nunley, J. \& Frankovitch, K. Lateral talocalcaneal angle in assessment of subtalar valgus: follow-up of seventy Grice-Green arthrodeses. Foot Ankle, 4(2):56-63, 1983.

Beatson, T. R. \& Pearson, J. R. A method of assessing correction in club feet. J. Bone Joint Surg. Br., 48(1):40-50, 1966.

Clare, M. P.; Lee, W. E. 3rd. \& Sanders, R. W. Intermediate to long-term results of a treatment protocol for calcaneal fracture malunions. J. Bone Joint Surg. Am., 87(5):963-73, 2005.

Davids, J. R.; Gibson, T. W. \& Pugh, L. I. Quantitative segmental analysis of weight-bearing radiographs of the foot and ankle for children: normal alignment. J. Pediatr. Orthop., 25(6):769$76,2005$. 
Dobbs, M. B.; Nunley, R. \& Schoenecker, P. L. Long-term followup of patients with clubfeet treated with extensive soft-tissue release. J. Bone Joint Surg. Am., 88(5):986-96, 2006.

Dooley, P.; Buckley, R.; Tough, S.; McCormack, B.; Pate, G.; Leighton, R.; et al. Bilateral calcaneal fractures: operative versus nonoperative treatment. Foot Ankle Int., 25(2):47-52, 2004.

Gentili, A.; Masih, S.; Yao, L. \& Seeger, L. L. Pictorial review: foot axes and angles. Br. J. Radiol., 69(826):968-74, 1996.

Igbigbi, P. S. \& Mutesasira, A. N. Calcaneal angle in Ugandans. Clin. Anat., 16(4):328-30, 2003.

Katz, M. A.; Davidson, R. S.; Chan, P. S. H. \& Sullivan, R. J. Plain Radiographic Evaluation of Paediatric foot and its Diagnosis. UPOJ, 10:30-9, 1997.

Knupp, M.; Schuh, R.; Stufkens, S. A.; Bolliger, L. \& Hintermann, B. Subtalar and talonavicular arthrodesis through a single medial approach for the correction of severe planovalgus deformity. J. Bone Joint Surg. Br., 91(5):612-5, 2009.

Mehrafshan, M.; Rampal, V.; Seringe, R. \& Wicart, P. Recurrent club-foot deformity following previous soft-tissue release: midterm outcome after revision surgery. J. Bone Joint Surg. Br., 91(7):949-54, 2009.

Park, K. B.; Park, H. W.; Lee, K. S.; Joo, S. Y. \& Kim, H. W. Changes in dynamic foot pressure after surgical treatment of valgus deformity of the hindfoot in cerebral palsy. J. Bone Joint Surg. Am., 90(8):1712-21, 2008.

Prichasuk, S. \& Subhadrabandhu, T. The relationship of pes planus and calcaneal spur to plantar heel pain. Clin. Orthop. Relat. Res., (306):192-6, 1994.

Radler, C.; Egermann, M.; Riedl, K.; Ganger, R. \& Grill, F. Interobserver reliability of radiographic measurements of contralateral feet of pediatric patients with unilateral clubfoot. J. Bone Joint Surg. Am., 92(14):2427-35, 2010.

Sangeorzan, B. Cavovarus foot. In: OrthopaedicsOne. The orthopaedic knowledge network. 2010. Available in: http:// www.orthopaedicsone.com/display/Main/Cavovarus + foot

Savva, N. \& Saxby, T. S. In situ arthrodesis with lateral-wall ostectomy for the sequelae of fracture of the os calcis. J. Bone Joint Surg. Br., 89(7):919-24, 2007.

Schwend, R. M. \& Drennan, J. C. Cavus foot deformity in children. J. Am. Acad. Orthop. Surg., 11(3):201-11, 2003.

Seyahi, A.; Uludag, S.; Koyuncu, L.; Taube, M.; Atalar, A. \& Demirhan, M. Böhler And Gissane Angles Of The Calcaneus: what Are The Normal Ranges? J. Bone Joint Surg. Br., 92B(Supp. II):297, 2010.
Turner, N. S.; Stephens, H. M.; Talavera, F.; Hurwitz, S. R.; Patel, D. \& Calhoun, J. H. Pes Cavus. 2005. Available in: www.emedicine.com

Westberry, D. E.; Davids, J. R.; Shaver, J. C.; Tanner, S. L.; Blackhurst, D. W. \& Davis, R. B. Impact of ankle-foot orthoses on static foot alignment in children with cerebral palsy. J. Bone Joint Surg. Am., 89(4):806-13, 2007.

Wisbrun, W. Nene Gesichtspunkte zum Redressement des angeborenen Klumpfusses und daraus sich ergebende Schluss folgerungen bezüglich der Atiologie. Arch. Orthop. UnfallChir., 31:451-64, 1932.

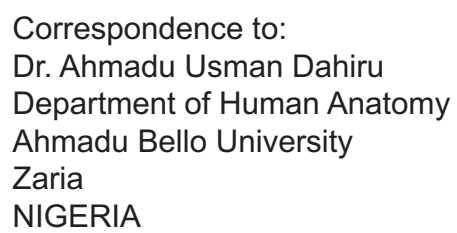

Tel: +2347086811341, +2348035183871

Email: audahiru@abu.edu.ng

Received: 26-06-2012

Accepted: 01-09-2012 